\title{
Who Are the Shareholders in Australia and What Are Their Ethical Opinions? An Empirical Analysis
}

\author{
Dallas Hanson* and Bruce Tranter
}

Analysis of the 2003 Australian Survey of Social Attitudes verifies claims that Australia is a share-owning democracy. We show that higher income earners are most likely to own shares and to own shares in a large number of companies, and that the 45-54 and 54-56 year age groups are the peak for ownership. We also investigate ethical issues relating to shareownership by examining scenarios under which owners would sell their shares.

Ethical concern is highest on the issue of child labour. Yet there is surprisingly little concern amongst shareowners over racial discrimination, which was less likely to lead to the sales of shares than investment in genetically modified crops or foods, paying large bonuses to executives or the production of military weapons. Women are more likely than men to adopt an "ethical" stance on share ownership across all scenarios, although high income earners are less likely to sell shares in the face of racial discrimination or the production of military weapons by their companies.

Postmaterialists are just as likely as materialists to own shares, but much more likely to sell them for ethical reasons, while those on the "left" of politics appear to be more ethical than the "right". Finally, owning shares in several companies reduces the likelihood of ethical behaviour, with those owning shares in six or more companies least likely to sell for any ethical reason.

Keywords: Share-owning, ethics, governance, child labour, racial discrimination

\section{Introduction}

A ustralia is a democracy in which around half the adult population directly own shares in corporations and an even greater number own shares through superannuation funds. For managers of such corporations this complicates an already difficult corporate landscape; how should they handle the mix of institutional and small shareholders? How best to handle increasingly active shareholder groups? To what extent does widespread shareholding alter the political landscape (hence corporate regulation)? To this mix we add the focus of the current research: To what extent do prominent social/ethical issues influence shareholder intention to sell or retain shares and what are the characteristics of such shareholders?

This extends earlier research into share ownership in Australia focused on the characteristics of shareholders (White et al., 2004) and the political implications of shareownership (Donoghue et al., 2003). Our aim in this research is to consider intentions to sell or keep shares, while in future work we will consider actual sales of ethically challenged shares.

\section{Method}

We developed a series of questions relating to share ownership that were included in the
*Address for correspondence: Faculty of Commerce Building, 305, Hobart Campus, Private Bag 16, University of Tasmania, Hobart, Tasmania 7000 Australia. Tel: +61 (0) 36226 1877; Fax: +61 (0) 362262808 ; E-mail:

dallas.hanson@utas.edu.au 
2003 Australian Survey of Social Attitudes (AuSSA; Gibson et al., 2004). ${ }^{1}$ The AuSSA is a new cross-sectional national survey of Australians aged 18 and over, the first in a biennial series. The sample was drawn on a systematic basis from the 2002 Australian Electoral Roll, with mail out, mail back administration of questionnaires conducted between 3 August and 24 December 2003. The sample was stratified so as to be proportional to the population size of each state, with two versions of the questionnaire administered to separate sub samples of approximately similar size. The survey containing the shares questions has a sample size of 2087. The variables used in the analyses are derived from the following questions:

1. Do you own shares in any company working on the Australian Stock Exchange (shares registered in your name or that of your family company) $?^{2}$

2. Thinking about the companies in which you own shares, would you keep or sell your shares in a company if you found out it had done the following?

The issues chosen for the ethics questions have immediate resonance in Australia (and arguably in other countries in the OECD) because all are topical and most are also issues of long standing. Indeed, four issues are corporate versions of concerns that are essentially timeless: harming the environment, using child labour, producing military weapons and being prosecuted for racial discrimination. The fifth item, "giving large bonuses to executives" is highly topical in Australia and, at least, the USA and UK because of widespread publicity over CEO remuneration over the past several years in prosperous capitalist nations. The sixth is a relatively recent but vexed issue that has attracted major publicity in Europe and Australia over the past five years, involvement in genetically modified foods.

Essential background to ethics and shareholders is a description of the share-ownership phenomenon in Australia and given the range of demographic variables included in the AUSSA we are also able to sketch this in the first section of the paper. In the second part we consider responses to questions on shareholding/selling and ethical issues before drawing conclusions.

\section{Share ownership in Australia: the phenomenon}

Share ownership in Australia has been increasing since the early 1990s when only around 14 per cent of people owned shares. As Table 1 indicates, this has grown to almost half of the adult population owning shares registered in their name or a company name.

On these numbers Australia can fairly be termed the share-owning democracy that Mark Latham, the leader of the opposition in 2004 refers to (see Latham and Botsman, 2001). This information is consistent with the Australian Stock Exchange's shareholder study of 2004, where it was evident that the percentage of the population in Australia that owns shares directly and indirectly was the highest in the world. Second was Canada, followed by the USA and the UK (ASX 2000, 2004). The finer texture of this is evident in the discussion of demographic factors on share ownership, summarised in Table 2.

Some gender differences in share ownership are apparent. In general, men are more likely than women to own shares, although the differences are not large. Notably, 7 per cent of men own shares in 10 or more companies, compared to only 3 per cent of women.

Age influences share ownership. The youngest and oldest age cohorts are least likely to own shares and those aged between 45 and 64 the most likely. This is easily explained in terms of the peak earning period in the Western life-cycle. The percentage of people owning shares in more than one company is interesting. In the 25-34 and 35-44 age groups it is only 17.2 and 25.7 per cent respectively of all people in these categories, while in the peak share-owning ages of 45-54 and 55-64 the percentage of people owning more than one share rises to 35.7 per cent and 38.8 per cent. It falls again for older groups with 65-74 at 34.4 per cent and $75+$ at 26.3 per cent. This is consistent, again, with the peak earning years providing more disposable income to buy portfolios of shares.

The one share-owner population that is part of this is a feature of the Australian shareownership phenomenon. Many of these investors would have entered the market through

Table 1: Do you own shares in any company working on the Australian Stock Exchange (shares registered in your name or that of your family company)? (\%)

$\begin{array}{lc}\text { No, don't own any shares } & 53.1 \\ \text { Yes, in 1 company } & 17.2 \\ \text { Yes, in 2-5 companies } & 19.1 \\ \text { Yes, in 6-10 companies } & 5.7 \\ \text { Yes, in more than 10 companies } & 4.9 \\ \text { N } & (2022)\end{array}$

Source: Australian Survey of Social Attitudes, 2003. 
Table 2: Social bases of share ownership (\%t)

\begin{tabular}{|c|c|c|c|c|c|}
\hline & $\begin{array}{l}\text { Don't own } \\
\text { shares }\end{array}$ & $\begin{array}{c}1 \\
\text { company }\end{array}$ & $\begin{array}{c}2-5 \\
\text { companies }\end{array}$ & $\begin{array}{c}\text { 6-10 } \\
\text { companies }\end{array}$ & $\begin{array}{c}10+ \\
\text { companies }\end{array}$ \\
\hline Women & 56.1 & 16.8 & 18.6 & 5.7 & 2.9 \\
\hline Men & 49.5 & 17.6 & 19.9 & 5.9 & 7.2 \\
\hline \multicolumn{6}{|l|}{$\begin{array}{l}\text { Cramer's V }=0.11 \\
\mathrm{p}<0.000\end{array}$} \\
\hline \multicolumn{6}{|l|}{ Age groups } \\
\hline $18-24$ & 76.4 & 13.4 & 7.1 & 2.4 & 0.8 \\
\hline $25-34$ & 62.5 & 20.2 & 13.9 & 1.4 & 1.9 \\
\hline $35-44$ & 52.3 & 22.0 & 19.2 & 2.6 & 3.9 \\
\hline $45-54$ & 44.9 & 19.4 & 22.1 & 8.0 & 5.6 \\
\hline $55-64$ & 45.8 & 15.4 & 23.2 & 7.8 & 7.8 \\
\hline $65-74$ & 54.7 & 10.9 & 19.9 & 9.0 & 5.5 \\
\hline $75+$ & 60.9 & 12.8 & 16.2 & 5.6 & 4.5 \\
\hline \multicolumn{5}{|l|}{ Cramer's V $=0.12$} & $\mathrm{p}<0.000$ \\
\hline \multicolumn{6}{|l|}{ Education level } \\
\hline Degree & 40.4 & 17.5 & 24.0 & 9.0 & 9.2 \\
\hline Diploma & 49.3 & 17.2 & 22.2 & 6.4 & 5.0 \\
\hline Trade qualification & 51.3 & 21.0 & 20.2 & 3.8 & 3.8 \\
\hline Completed Year 12 & 56.6 & 19.6 & 14.2 & 5.5 & 4.1 \\
\hline Completed Year 10 & 56.9 & 17.2 & 16.6 & 6.1 & 3.2 \\
\hline Year 10 not complete & 69.9 & 12.6 & 14.0 & 1.4 & 2.1 \\
\hline \multicolumn{6}{|l|}{$\begin{array}{l}\text { Cramer's V }=0.11 \\
\mathrm{p}<0.000\end{array}$} \\
\hline \multicolumn{6}{|l|}{ Income groups } \\
\hline$\$ 0-20,799$ & 62.5 & 16.1 & 16.1 & 3.7 & 1.4 \\
\hline$\$ 20,800-31,199$ & 56.5 & 18.1 & 15.6 & 6.3 & 3.5 \\
\hline$\$ 31,200-36,399$ & 56.0 & 15.5 & 19.5 & 5.4 & 3.6 \\
\hline$\$ 41,600-51,999$ & 40.9 & 19.5 & 23.8 & 6.1 & 9.8 \\
\hline$\$ 52,000-77,799$ & 39.9 & 21.5 & 22.9 & 7.6 & 8.1 \\
\hline$\$ 77,800+$ & 23.4 & 11.7 & 34.5 & 11.7 & 18.6 \\
\hline \multicolumn{6}{|l|}{$\begin{array}{l}\text { Cramer's V }=0.16 \\
p<0.000\end{array}$} \\
\hline \multicolumn{6}{|l|}{ Self-assessed class } \\
\hline Middle class & 41.8 & 18.1 & 23.8 & 7.6 & 8.7 \\
\hline Working/none & 65.0 & 16.2 & 14.0 & 3.7 & 1.0 \\
\hline \multicolumn{6}{|l|}{$\begin{array}{l}\text { Cramer's V }=0.27 \\
p<0.000\end{array}$} \\
\hline \multicolumn{6}{|l|}{ Value orientations } \\
\hline Postmaterialists & 54.0 & 16.1 & 18.5 & 6.3 & 5.0 \\
\hline Mixed & 52.9 & 17.2 & 19.3 & 5.7 & 4.9 \\
\hline Materialists & 54.1 & 17.8 & 18.8 & 5.4 & 3.8 \\
\hline \multicolumn{6}{|l|}{$\begin{array}{l}\text { Cramer's V }=0.02 \\
p<0.992\end{array}$} \\
\hline \multicolumn{6}{|l|}{ Political ideology } \\
\hline Left & 52.2 & 18.7 & 17.8 & 5.7 & 5.7 \\
\hline Centre & 52.4 & 18.6 & 19.6 & 5.1 & 4.4 \\
\hline Right & 43.7 & 12.3 & 23.8 & 10.7 & 9.4 \\
\hline \multicolumn{6}{|l|}{$\begin{array}{l}\text { Cramer's V }=0.12 \\
\mathfrak{p}<0.000\end{array}$} \\
\hline All & 53.0 & 17.1 & 19.2 & 5.8 & 4.9 \\
\hline
\end{tabular}

Source: Australian Survey of Social Attitudes, 2003. 
the wave of demutualisations and partial privatisations of the 1990s and the fact that Coles/Myer, a big grocery retailer had a shareholder discount scheme in place for much of the 1990s. This contributed to an increase in the number of their shareholders from less than 100,000 to 565,000 between 1992 and 2000. Telstra, the partially privatised Telco, had 2,037,000 shareholders in the year 2000, while the demutualised motoring organisation from the state of NSW, the NRMA, had $1,666,000$ and the AMP, a leading insurance company, had 1,026,000. Many of these shareholders are likely to be single share-owners represented in Table 2 who were prompted to buy because of the publicity surrounding the float of these corporations and by the fact that they "knew about" the new shares. The total population of Australia in 2003 was just under 20,000,000 (ABS, 2003, 3101.0 Table 6) which means that approximately 20 per cent of the population owned Telstra shares and 10 per cent AMP shares at that time, an extraordinary penetration of the shareowners market by these companies.

Share ownership increases in a linear manner with educational achievement with approximately 60 per cent of university graduates owning shares and only around 30 per cent of those who did not complete the usual minimum standard education in Australia of grade 10 . The pattern evident in numbers of companies in which shares are owned is also interesting, with 18.2 per cent of degree holders owning more than six shares and only 3.5 per cent in the category of non-completions of grade 10.

A similar (and no doubt related) positive linear effect is also evident with income with a steady increase in ownership as income increases evident. In the $\$ 52,000-77,799$ group around 60 per cent owned shares, and at incomes above this 77 per cent owned shares. These income levels are not unusual given that Australian average annual income for fulltime workers in 2003 was $\$ 51,298$ (ABS, 2003, 31101). Again, the assertion of a share-owning democracy is supported. In higher income groups the proportions of people owning shares in more than six different companies is very high, with 65 per cent of those with incomes of $\$ 77,800+$ in this category and only 11.7 per cent owning shares in only one company. From this we can surmise that higher income Australians have a focus on shareholding. For the $\$ 52,000-77,799$ category the percentages are lower but still considerable, with 38.6 per cent owning shares in more than one company. ${ }^{3}$

Share ownership is also influenced by social class location, with middle-class people much more likely to own shares than the working class, particularly so among those who own shares in 10 or more companies. Given that class was self-selected in the AuSSA survey, there is something of a circle evident here: class selected is likely to be heavily influenced by the fact of share ownership. Also unsurprisingly, political ideology is related to ownership, with those who identify with the "right" of politics more likely than the "left" or centrists to own shares. ${ }^{4}$

We also seek to assess the impact of value orientations on share ownership. Inglehart (1977, 1997) claims that postmaterialists are more likely than materialists to be concerned over quality of life issues, such as the environment, social justice and human rights, as opposed to materialist economic issues. ${ }^{5}$ However, the value orientations scale is the only independent variable in these analyses that does not show a statistically significant relationship with share ownership. In fact, postmaterialists are just as likely as materialists to own shares.

We now consider share ownership in the multivariate case, predicting ownership versus non-ownership on the basis of the values of our independent variables and a dichotomous share ownership dependent variable. The results presented are odds ratios from a binary logistic regression analysis (Table 3 ).

As the resulting dependent variables comprise a series of dichotomous (i.e. own or don't own shares; sell or keep shares) answers, logistic regression was employed as an appropriate method of analysis (see Long, 1997). Odds ratios are presented in the regression tables. Odds ratios calculated from the logits (i.e. the exponential of the logit is interpretable as an odds ratio) facilitate the interpretation of the logistic regression estimates. In the multiple logistic regression results presented in Table 3, odds ratios for scale variables represent the difference between the extreme values on each scale. Odds ratios for dummy variables contrast each dummy variable with its respective reference category. For example, in Table 3, those with a degree are 1.3 times as likely at the non-tertiary educated to own shares rather than not own shares, after controlling for the influence of other independent variables in the regression model. Negative estimates are expressed as odds ratios less than unity. For example, the odds ratio of 0.6 for the $\$ 52,000$ 77,790 income category suggests that this category is 1.7 times less likely (i.e. $1 / 0.6=1.67$ ) than the highest income reference category to own shares.

In the multivariate model, gender is no longer a significant predictor of ownership. However, the youngest age cohort is substan- 
tially less likely to own shares than the oldest, and those in the 55-64 years group are about twice as likely to own shares as the oldest respondents (i.e. 65+). A fairly linear pattern emerges for income in the multivariate case,

Table 3: Social bases of share ownership (odds ratios)

Own shares

\begin{tabular}{ll}
\hline Women & 0.9 \\
Men & 1 \\
Age groups & \\
18-24 & $0.4^{* *}$ \\
$25-34$ & 0.6 \\
35-44 & 1.0 \\
$45-54$ & 1.4 \\
$55-64$ & $1.7^{*}$ \\
65-74 & 1.4 \\
$75+$ & 1 \\
Education level & \\
Degree & $1.3^{*}$ \\
Income groups & \\
\$0-20,799 & $0.3^{* * *}$ \\
\$20,800-31,199 & $0.4^{* * *}$ \\
\$31,200-36,399 & $0.4^{* * *}$ \\
\$41,600-51,999 & 0.6 \\
\$52,000-77,799 & $0.6^{*}$ \\
\$77,800+ & 1 \\
Self-assessed class & \\
Middle class & $2.0^{* * *}$ \\
Value orientations & \\
Postmaterial scale & \\
Political ideology & \\
Ideology scale & \\
R-squared & 1.04 \\
\hline
\end{tabular}

Source: Australian Survey of Social Attitudes, 2003. with ownership decreasing with income. A weak education effect is apparent. Those with degrees are approximately 1.3 times as likely as other education levels to own shares. The only remaining significant effect is related to self-assessed social class, with those who identify as middle class about twice as likely to own shares as the working class. The r-squared of 0.15 suggests that the model "explains" a reasonable amount of the variation in share ownership given that these are social survey data.

\section{Ethical thinking and share ownership}

The results presented in the first three tables sketch a profile of the social and ideological bases of share ownership. We now turn to the six hypothetical scenarios that may lead investors to sell (Tables 4, 5 and 6). Table 4 presents a summary of responses to the six ethical questions measuring intent to keep or sell shares.

Basic conclusions for this level of analysis are mixed. Several issues attracted a strong "sell" orientation, arguably the best indication of a strongly ethical stance in share ownership. For example, the 61 per cent of Australians who suggest that "Using child labour" would cause them to sell is an unambiguous indicator of ethical intentions, although several of the other questions also received relatively strong support for selling shares. On these figures shareholders, generally speaking, appear to operate as (impliedly) ethical beings rather than just profit-oriented investors.

Adding the "probably sell" numbers into the mix provides an even more ethically coloured, but complex, canvas. For the "used child labour" question, 88.2 per cent would probably or definitely sell. "Caused a major environmental problem" had 70.9 per cent either definitely or probably selling;

Table 4: Thinking about the companies in which you own shares, would you keep or sell your shares in a company if you found out it had done the following (\%)

\begin{tabular}{lcccc}
\hline & $\begin{array}{c}\text { Definitely } \\
\text { keep }\end{array}$ & $\begin{array}{c}\text { Probably } \\
\text { keep }\end{array}$ & $\begin{array}{c}\text { Probably } \\
\text { sell }\end{array}$ & $\begin{array}{c}\text { Definitely } \\
\text { sell }\end{array}$ \\
\hline Caused a major environmental problem & 2.9 & 26.2 & 42.6 & 28.3 \\
Used child labour & 1.7 & 10.1 & 27.4 & 60.8 \\
Produced military weapons & 7.1 & 34.7 & 21.1 & 37.1 \\
Gave large bonuses to its executives & 2.6 & 37.2 & 31.2 & 28.9 \\
Invested in genetically modified crops or food & 3.3 & 29.1 & 37.5 & 30.0 \\
Been prosecuted for racial discrimination & 5.4 & 46.0 & 26.9 & 21.6 \\
\hline
\end{tabular}

Source: Australian Survey of Social Attitudes, 2003. 
Table 5: Would keep (probably plus definitely) shares in companies who ... (\%)

\begin{tabular}{|c|c|c|c|c|c|c|}
\hline & $\begin{array}{c}\text { Cause } \\
\text { environmental } \\
\text { problem }\end{array}$ & $\begin{array}{l}\text { Use } \\
\text { child } \\
\text { labour }\end{array}$ & $\begin{array}{c}\text { Produce } \\
\text { military } \\
\text { weapons }\end{array}$ & $\begin{array}{l}\text { Pay large } \\
\text { bonuses to } \\
\text { executives }\end{array}$ & $\begin{array}{l}\text { Produce } \\
\text { GM food } \\
\text { or crops }\end{array}$ & $\begin{array}{c}\text { Racially } \\
\text { discriminate }\end{array}$ \\
\hline Women & 22.1 & 8.3 & 25.3 & 33.9 & 27.2 & 41.3 \\
\hline Men & 35.4 & 15.0 & 57.1 & 45.8 & 37.7 & 60.7 \\
\hline Cramer's V = & 0.16 & 0.10 & 0.32 & 0.12 & 0.11 & 0.19 \\
\hline $\mathrm{p}<$ & 0.000 & 0.002 & 0.000 & 0.000 & 0.001 & 0.000 \\
\hline \multicolumn{7}{|l|}{ Age groups (75+) } \\
\hline $18-24$ & 37.0 & 7.1 & 32.1 & 57.1 & 32.1 & 70.4 \\
\hline $25-34$ & 28.2 & 11.1 & 38.8 & 53.7 & 27.4 & 47.5 \\
\hline $35-44$ & 29.0 & 15.1 & 44.2 & 44.5 & 31.4 & 54.1 \\
\hline $45-54$ & 24.9 & 9.7 & 38.9 & 39.3 & 30.3 & 52.5 \\
\hline $55-64$ & 25.1 & 10.1 & 37.0 & 33.3 & 32.4 & 43.5 \\
\hline $65-74$ & 36.6 & 16.3 & 49.5 & 39.4 & 44.9 & 52.0 \\
\hline $75+$ & 35.1 & 10.0 & 51.8 & 25.4 & 25.0 & 60.7 \\
\hline Cramer's V = & 0.10 & 0.09 & 0.11 & 0.15 & 0.11 & 0.12 \\
\hline $\mathrm{p} \leq$ & 0.246 & 0.411 & 0.181 & 0.004 & 0.143 & 0.078 \\
\hline Degree & 24.8 & 8.9 & 33.6 & 49.1 & 27.6 & 56.8 \\
\hline Diploma & 27.6 & 11.5 & 38.6 & 37.2 & 34.4 & 46.6 \\
\hline Trade qualification & 35.2 & 15.6 & 61.0 & 38.1 & 40.0 & 54.6 \\
\hline Completed Year 12 & 36.9 & 13.1 & 46.8 & 47.6 & 33.7 & 54.4 \\
\hline Completed Year 10 & 26.8 & 14.3 & 39.8 & 34.1 & 31.7 & 50.4 \\
\hline Year 10 not complete & 31.6 & 10.3 & 44.0 & 23.4 & 32.9 & 41.9 \\
\hline Cramer's V $=$ & 0.10 & 0.07 & 0.17 & 0.16 & 0.08 & 0.10 \\
\hline $\mathrm{p} \leq$ & 0.199 & 0.462 & 0.000 & 0.001 & 0.355 & 0.175 \\
\hline \multicolumn{7}{|l|}{ Income groups } \\
\hline$\$ 0-20,799$ & 25.8 & 10.5 & 39.6 & 32.6 & 31.9 & 45.9 \\
\hline$\$ 20,800-31,199$ & 31.1 & 11.9 & 35.9 & 34.7 & 27.3 & 45.1 \\
\hline$\$ 31,200-36,399$ & 27.5 & 10.0 & 36.6 & 31.4 & 26.0 & 50.5 \\
\hline$\$ 41,600-51,999$ & 24.1 & 13.0 & 46.1 & 44.0 & 31.4 & 54.2 \\
\hline$\$ 52,000-77,799$ & 34.8 & 11.6 & 40.4 & 43.5 & 39.5 & 54.0 \\
\hline$\$ 77,800+$ & 31.7 & 15.4 & 57.4 & 64.0 & 38.1 & 72.0 \\
\hline Cramer's V = & 0.08 & 0.05 & 0.13 & 0.21 & 0.10 & 0.17 \\
\hline $\mathrm{p} \leq$ & 0.431 & 0.818 & 0.019 & 0.000 & 0.188 & 0.001 \\
\hline Middle class & 28.1 & 11.4 & 41.2 & 44.7 & 32.5 & 54.5 \\
\hline Working/none & 31.2 & 12.5 & 42.1 & 32.5 & 32.2 & 45.6 \\
\hline Cramer's V = & 0.03 & 0.02 & 0.01 & 0.12 & 0.00 & 0.09 \\
\hline $\mathrm{p} \leq$ & 0.357 & 0.652 & 0.796 & 0.001 & 0.923 & 0.017 \\
\hline Postmaterialists & 17.2 & 4.9 & 21.8 & 34.6 & 20.6 & 40.1 \\
\hline Mixed & 29.5 & 12.4 & 45.0 & 41.4 & 34.4 & 53.0 \\
\hline Materialists & 41.8 & 16.9 & 50.8 & 37.0 & 38.7 & 57.5 \\
\hline Cramer's V = & 0.16 & 0.11 & 0.20 & 0.06 & 0.13 & 0.11 \\
\hline $\mathrm{p} \leq$ & 0.000 & 0.004 & 0.000 & 0.258 & 0.002 & 0.007 \\
\hline Left & 14.6 & 4.7 & 18.6 & 39.0 & 17.9 & 37.0 \\
\hline Centre & 26.5 & 11.4 & 39.9 & 35.6 & 27.6 & 50.5 \\
\hline Right & 38.5 & 14.0 & 57.1 & 49.4 & 48.2 & 64.8 \\
\hline Cramer's V = & 0.18 & 0.09 & 0.26 & 0.13 & 0.24 & 0.19 \\
\hline $\mathrm{p}<$ & 0.000 & 0.042 & 0.000 & 0.004 & 0.000 & 0.000 \\
\hline \multicolumn{7}{|l|}{ Own shares } \\
\hline Shares in one company & 23.4 & 11.0 & 36.8 & 31.3 & 24.9 & 44.0 \\
\hline 2-5 companies & 32.9 & 10.8 & 42.0 & 36.9 & 35.8 & 50.0 \\
\hline 6-10 companies & 35.6 & 15.7 & 42.7 & 61.5 & 39.0 & 59.0 \\
\hline More than 10 companies & 27.3 & 14.9 & 58.8 & 58.5 & 39.8 & 72.9 \\
\hline Cramer's V = & 0.11 & 0.06 & 0.13 & 0.23 & 0.13 & 0.18 \\
\hline $\mathrm{p}<$ & 0.025 & 0.398 & 0.004 & 0.000 & 0.004 & 0.000 \\
\hline All & 29.1 & 11.8 & 41.8 & 39.9 & 32.5 & 51.5 \\
\hline
\end{tabular}

Source: Australian Survey of Social Attitudes, 2003. 


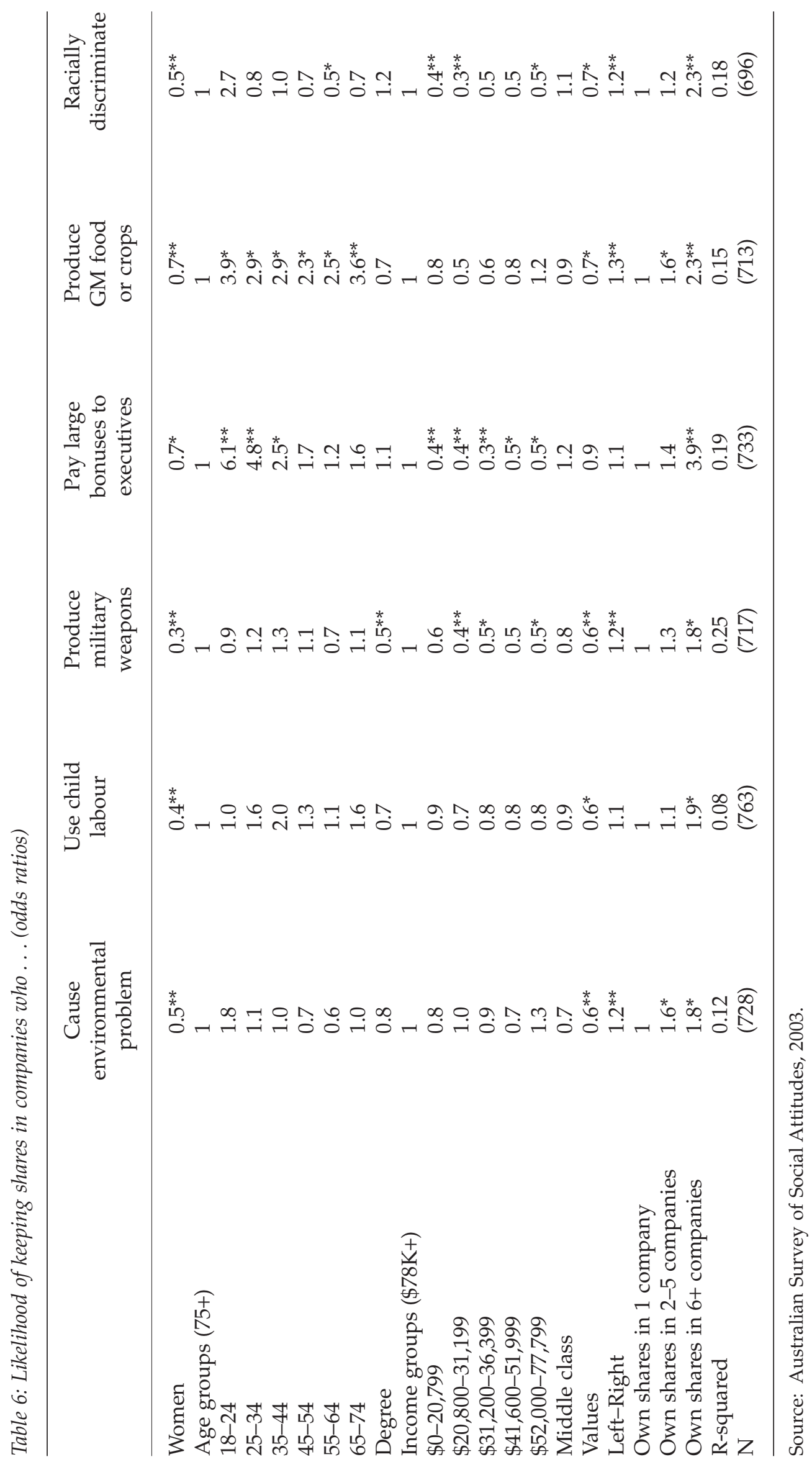


"produced military weapons", 58.2 per cent (perhaps an artefact of the Gulf war, but a disappointing percentage for those opposing war); "gave large bonuses to executives", 60.1 (perhaps related to publicity abut CEO pay in Australia in 2003); "invested in genetically modified crops or food", 67.5 per cent (arguably related to publicity about GM foods in Australia in 2003); and "been prosecuted for racial discrimination", 48.5 per cent definitely or probably sell.

What is interesting here is the strong support for the long-established ethical area of child labour but the relatively weak support for the equally well-established area of racial discrimination. The importance of these issues varies within the large group of shareholders surveyed. Put the other way, 51.4 per cent of shareholders said they would definitely or probably keep shares if the company had "Been prosecuted for racial discrimination". The statement is unambiguous and anchored in a definite action ("prosecuted") making the percentage surprising given the significance of race as an issue in the Western world over the last 50 years. In contrast, only 11.8 per cent would definitely or probably keep shares in companies that used child labour. This issue remains extremely important to people. The percentages for keep and sell for the more recent issues of investment in genetically modified foods and bonuses for executives can best be explained as related to recent publicity over these issues - shareowners read the newspapers and watch TV news and react to the information provided.

A bivariate analysis of the demographics of the ethical data extends this discussion. It is outlined in Table 5.

Gender is related to ethical decision making in a statistically significant manner across all six of the questions, but most notably for producing military weapons. Only 25 per cent of women would definitely or probably keep their shares in a company they discovered was producing military weapons, compared to 57 per cent of men. Age is less clearly related to selling or keeping shares, and only differentiates on the question relating to paying bonuses to executives, with younger people less likely to sell for this reason.

Education level too, is only a useful indicator of selling or keeping shares for two questions - producing military weapons and paying large bonuses to executives. Those with trade qualifications (61 per cent) were least likely to sell shares if their company produced military weapons, while tertiary education increased the likelihood of selling for this reason - with only 34 per cent of those with degrees saying they would keep their shares.
On the other hand, tertiary graduates were least likely to sell because of large bonus payments to executives. Perhaps predictably also, the likelihood of selling because of executive bonuses tends to decrease as income rises, with those on the highest incomes least likely to sell for this reason. Similarly, the propensity to sell when companies produce military weapons reduces as income increases, with the ethical importance of racial discrimination declining with increases in income. Selfidentified class is not a particularly influential predictor of ethical behaviour in share ownership, although the middle class are more likely than the working class to keep their shares in the face of racial discrimination or large bonus payments to executives.

With the exception of executive bonuses, postmaterialists appear to be more ethical than materialists across the board. This finding contrasts with actual ownership of shares (see Table 3) where postmaterialists are as likely as materialists to actually own shares, but is consistent with postmaterialist concern for human rights and social justice (Inglehart, 1997, p. 244). Our findings suggest that value orientations are also an important indicator of ethical concerns. The left also claims to be more ethical than the right for all six scenario questions, which is not unexpected, although empirical verification is an interesting finding. These results suggest an alignment of the left-right ideological dimension with the postmaterialist-materialist dimension, with postmaterialists and the left overlapping on ethical concerns in a manner consistent with the political cleavages identified by Ingehart (1997, p. 248).

Finally, with the exception of the child labour question, the more companies one owns shares in, the less likely one is to let ethics get in the way of a profit-making opportunity.

The bivariate analyses show several interesting associations between our independent variables and the "sell scenario" questions. In the multivariate case (Table 6), gender remains a significant predictor of all dependent variables. It is particularly important for disposing of shares in relation to companies that produce military weapons - with women more than three times as likely as men to sell shares under these circumstances. However, while they are important predictors on some dependent variables, income, age and education are less consistent predictors in the multivariate model. Higher income tends to be associated with a reluctance to keep shares on the military weapons, large bonuses and racial discrimination questions. Education is an important predictor for the military weapons 
dependent variable only, with the tertiary educated about twice as likely to sell their shares for this reason as non-graduates.

Unlike share ownership in general, value orientations are a significant predictor of all scenarios, with the exception of paying large bonuses to executives. Materialists are more likely than postmaterialists to say they would keep their shares under five of the six scenarios here. So while their level of share ownership is approximately equal, materialists, as their name suggests, tend to be much less ethical than postmaterialists across a range of measures. Positioning oneself on the right of the political spectrum is also an important predictor in four of the six scenario questions, with the exception of child labour and paying large bonuses. In all other cases the right are less ethical than the left.

Finally, an interesting - though perhaps not unexpected finding - is that even after controlling for a range of other factors, owning shares in six or more companies significantly increases the likelihood of retaining shares for all of these six scenarios. ${ }^{6}$ Perhaps we can extrapolate somewhat here (as we are unable to directly measure this) to suggest that shareholders with larger portfolios are generally more resistant to selling regardless of ethical considerations.

The magnitude of the r-squared statistics suggest that our model is quite a good predictor of the military weapons (0.25), paying large bonuses (0.19) and racial discrimination (0.18) dependent variables, although has considerably less explanatory value for the child labour variable (0.08). The small percentage of variation "explained" for the latter question is consistent with the fact that child labour elicits the strongest urge to sell shares of all of these scenario questions (see Table 4).

\section{Conclusion}

Australia can fairly be called a share-owning democracy because it has the highest proportion of shareowners of any country. This is a significant issue for any government; it is reasonable to argue that interest in shares and the market for shares increases the level of general interest in economic issues. For corporations, it means that their direct links with society are greater because more people are involved in their activities. This is particularly so for corporations such as Coles/Myer and Telstra, where there are many individuals that must, under the listing laws, be communicated with through annual reports and other reports.

However, shareowners are not a unitary mass. There are important demographic vari- ations in share ownership, which make the job of corporations in dealing with their shareholders more complex. This extends beyond the scope of obvious pressure groups such as green groups that operate to influence company policy.

For a start, the higher the income the greater the likelihood of owning shares, and in particular of owning more than one, and then six or more, shares. Also, the young and the postretirement age cohorts are less likely to own shares than the older age cohorts, with the 4554 and 54-65 age groups the peak ownership groups.

Shareowners are also divided in the area of ethics and share ownership is an area that it is reasonable to suggest may have significance to shareholders. If "definitely sell" shares is an indication of ethical tendencies for unethical company activity, there is only moderate support for most of the six hypothetical situations we used to encompass ethical areas of general concern. However, adding in the "probably sell" shows that considerable proportions of shareholders have ethical concerns that influence their shareholding. This peaked at 88.8 per cent for concerns about child labour, although fell to only 48.5 per cent for concerns about racial discrimination. The differences in percentage support for scenarios may have been influenced by publicity current at the time of the survey more than embedded legitimacy of the ethical issues we put forward. It is also worth emphasising that female shareowners are more ethically inclined than males - a simple division in the large field of shareowners that has important implications for corporate communication.

For managers, all the ethical cohorts are nevertheless sizeable and this means that all the ethical issues we put forward are important in policymaking and in particular in governance debates that bear on ethical issues. The mix of shareholders that must be borne in mind in such debates, then, is not only the distinction between institutional and small shareholders, but between different groups of ethically concerned people within the broad group of small shareholders. The size of these groups obviously extends well beyond the high profile green-shareholder pressure groups that have emerged in Australia in recent years and well-established pressure groups such as the Australian Shareholders Association.

These observations apply specifically to Australia, but are also important for other shareholding nations such as the USA, UK and Germany. The detail will no doubt be different between nations and since this paper focuses on Australia the material in it provides a 
reference point for other researchers to compare patterns in ownership in other countries.

\section{Notes}

1. The AuSSA data were obtained from the Australian Social Sciences Data Archive, Australian National University, Canberra.

2. The response categories for the share ownership questions were: 1 . No, don't own any shares; 2. Yes, in 1 company; 3 . Yes, in 2-5 companies; 4. Yes, in 6-10 companies; 5. Yes, in more than 10 companies.

3. The proportions of respondents in the various income categories are as follows: \$0-20,799: 41.6 per cent; $\$ 20,800-31,199 \mathrm{~K}$ : 16.6 per cent; $\$ 31,200$ 36,399: 12.9 per cent; $\$ 41,600-51,999$ : 8.8 per cent; $\$ 52,000-77,999$ : 12.3 per cent; and $\$ 78,000$ plus: 7.8 per cent.

4. Political ideology is measured with the following question: "In politics, people sometimes refer to being on the left or on the right. Where would you place yourself on a scale from 0 to 10 where 0 means the left and 10 means the right?" (emphasis in original). The original scoring of 0 (left) to 10 (right) is retained for the regression analyses.

5. Inglehart (e.g. 1977, p. 28) often uses a question to measure value orientations where respondents are asked to choose their most important and second most important national goals from the following list of options:

1. Maintain order in the nation.

2. Give people more say in important government decisions.

3. Protect freedom of speech.

4. Maintain a high rate of economic growth.

Those who choose options 1 and 3, regardless of the order of their choice, are deemed "materialists". Respondents who choose any combination of options 2 and 4 are classified as "postmaterialists". The remainder comprise the conceptually less interesting but largest category - "mixed" values. A three-point scale is usually constructed from these categories in the manner we employ in these analyses $(1=$ materialists; 3 = mixed; 3 = postmaterialists).

6. A dummy variable was included to represent those who own shares in 2-5 companies, or those who own shares in 6 or more companies. These groups were combined given the low numbers of respondents in each category.

\section{References}

ABS (2003) Australian Demographic Statistics. Table 3101.0. Canberra: Australian Bureau of Statistics. ASX (2000) Shareownership Study. Sydney: Australian Stock Exchange.

ASX (2004) Shareownership Study. Sydney: Australian Stock Exchange.

Donoghue, J., Tranter, B. and White, R. (2003) Homeownership, Shareownership and Coalition Policy, Journal of Australian Political Economy, 52, 58-82.

Gibson, R., Wilson, S., Meagher, G., Denemark, D. and Western, M. (2004) The Australian Survey of Social Attitudes, 2003 [Study number D1070]. Canberra: Australian National University.

Inglehart, R. (1977) The Silent Revolution: Changing Values and Political Styles Among Western Publics. Princeton, NJ: Princeton University Press.

Inglehart, R. (1997) Modernization and Postmodernization: Cultural, Economic and Political Change in 43 Societies. Princeton, NJ: Princeton University Press.

Latham, M. and Botsman, P. (2001) The Enabling State. Sydney: Pluto Press.

Long, J. Scott (1997) Regression Models for Categorical and Limited Dependent Variables. Thousand Oaks, CA: Sage.

White, R., Tranter, B. and Hanson, D. (2004) Shareownership in Australia: A Preliminary Review, Journal of Sociology, 40, 99-120.

Dallas Hanson lectures in strategic management at the University of Tasmania. He is interested in the intricacies of share ownership and the rationality of business.

Bruce Tranter lectures in sociology at the University of Tasmania. In addition to share ownership, his research interests include environmental sociology, voting behaviour and values research.

' $84 \%$ of SME directors consider Corporate Governance as "essential to their company's prospects".' IoD (Scotland) Survey, 2005. 
Copyright of Corporate Governance: An International Review is the property of Blackwell Publishing Limited and its content may not be copied or emailed to multiple sites or posted to a listserv without the copyright holder's express written permission. However, users may print, download, or email articles for individual use. 